\title{
Efficiency of solar radiation conversion in photovoltaic panels
}

\author{
Stawomir Kurpaska, Jarosław Knaga, Hubert Latała, Jakub Sikora and Wiestaw Tomczyk \\ ${ }^{1}$ Faculty of Production and Power Engineering, University of Agriculture in Krakow, 30-149 Krakow, Poland
}

\begin{abstract}
This paper included analysis the conversion efficiency in photovoltaic panels. The tests were done between February and June at a test stand equipped with three commonly used types of photovoltaic panels: poly- and monocrystalline silicon and with semi-conductive layer made of copper $(\mathrm{Cu})$, indium (In), gallium (Ga) and selenium (Se) (CIGS). Five days of each month were selected for a detailed analysis. They were close to the so-called recommended day for calculations in solar power engineering. Efficiency, calculated as the yield of electrical energy in relation to solar radiation energy reaching the panels was made conditional upon solar radiation intensity and ambient temperature. It was found that as solar radiation intensity and ambient temperature increase, the efficiency of solar radiation conversion into electricity is reduced. Correlation dependence was determined for the test data obtained, describing temperature change of panels depending on climatic conditions. It was found that as panel temperature increases, the conversion efficiency is reduced. Within the tested scope of experiment conditions, the efficiency was reduced in the range between 20.1 and $22.8 \%$. The authors also determined the average efficiency values in individual test months together with average ambient conditions of the environment where the process of solar radiation conversion took place.
\end{abstract}

\section{Introduction}

Care of natural environment, real threat of energy crisis as the effect of fossil fuel depletion stimulate the diversification of the present sources of energy and in consequence - the use of renewable energy sources. One of such sources is the energy of solar radiation. It results from the fact that the total amount of solar radiation reaching the surface of the Earth throughout the year is 1,800 times bigger than the current annual world demand for energy [13]. That is why it is becoming increasingly more popular to obtain electricity using the photovoltaic effect. Sun is the strongest source of light reaching the Earth, radiating energy generated as the result of thermonuclear reactions happening within. It emits radiation in all the ranges of electromagnetic waves. The biggest amount of energy $-49 \%$ is radiated within visible spectrum (380 $\div 760 \mathrm{~nm}$ wavelength) [11]. There are two methods of direct use of solar radiation energy - photothermal conversion (into heat) and photovoltaic conversion, i.e. converting solar radiation energy into electrical energy with the use of the photovoltaic effect. In the past 10 years, there has been a huge development as far as materials and technology used to produce photovoltaic cells and modules is concerned. In Europe, with the programs promoting photovoltaics as a safe and clean source of energy used by some countries (e.g. Germany, Spain), photovoltaic industry is growing extremely fast. Over the decade, we have observed annual increase in PV module production by $45 \%$ [9]. Widespread use of solar energy is conditional upon the cost of equipment and the efficiency of solar radiation conversion. The issue of the efficiency of photovoltaic panels has been analysed, for instance by Lu and Yang [3]. The authors determined the amount of generated electricity and the period of return of financial investment in photovoltaic system found on the roof of a building. They also did simulation studies for a diverse spatial set-up of the panels. In their work, Ortega-Izquierdo and Río [6] analysed systems of generating electricity from renewable sources, including photovoltaic panels, commonly implemented in chosen EU countries. They identified benefits, both economical and related to natural environment protection as well as to local labour market growth. Virtuani and Strepparav [12] studied the effects of work of photovoltaic modules made of crystalline silicon, by analysing their operational efficiency as compared to the efficiency determined for standard conditions. The analysis was performed for a southoriented, horizontal system integrated in a building. New type of modules was analysed by Smyrnakis et al. [10], who, under laboratory conditions, studied the observed effects related to current flow for cells based on silicon nanotubes. They used radiation in visible spectrum as the source of light. Makrides et al. [4] reviewed the most popular photovoltaic systems and provided nominal efficiencies of their conversion. During their studies they compared the efficiency of elements of an identical photovoltaic system mounted in Nicosia and Stuttgart and determined the differences

* Corresponding author: rtkurpas@cyf-kr.edu.pl 
in the amount of produced electricity. Hilse and Kapała [1] determined the efficiency of rotational and stationary panels as well as the ability to cover the energy demand of an object. Moharil and Kularni [5] presented their own simulation program concluding that it is useful, and that apart from determining photovoltaic energy results it also allows to determine planned financial expenses. Schallenberg-Rodri'guez [8] developed a method of estimating the effects of radiation conversion in photovoltaic modules mounted on the roof of residential buildings. This method, being an alternative for many commercial methods, includes the electric energy potential of panels (mono- and polycrystalline) mounted on the roofs of buildings, which depends on the availability of solar energy. It also allows to analyse the costs of such investment. The method was tested in the region of the Canary Islands. Zhai et al. [14] determined the value of harmful substance emissions to the atmosphere with natural gas and coal burning in power plants as well as with the use of photovoltaic panels in selected states of the USA. Based on standard relationships, Latała and Kurpaska [2] calculated theoretical efficiency of silicon panel with different angles found in the region of south Poland.

The review of studies reveals that the issue of producing electricity in photovoltaic panels is analysed in various research centres. Hence, the aim of this paper is to determine the effects of using photovoltaic panels to produce electrical energy, in field tests.

\section{Material and method}

Studies were performed on a stand built of three panel types (monocrystalline silicon, polycrystalline silicon and CIGS) localised within the Faculty of Production and Power Engineering of University of Agriculture in Krakow. The area of individual panels is: monocrystalline $27.2 \mathrm{~m}^{2}$, polycrstalline $27.2 \mathrm{~m}^{2}$ and CIGS- $40.1 \mathrm{~m}^{2}$. Figure 1 shows a schematic drawing of the test stand.

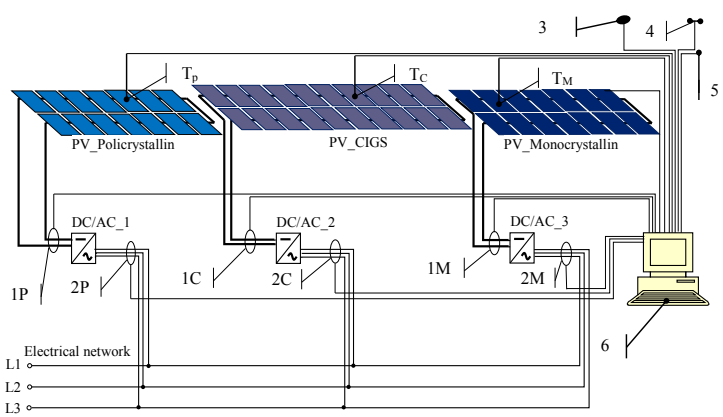

Fig. 1. Test stand schematic drawing.

The test stand is connected to the network by means of three-phase identical inverters (marked in fig. 1: $\mathrm{DC} / \mathrm{AC} \_1 . .3$ ). On primary side, in front of every inverter, a direct-current measurement module (1P, $1 \mathrm{C}, 1 \mathrm{M})$ was installed, whereas on secondary side there was an alternate-current module (2P, 2C, 2M). During the tests, the authors measured electrical energy yield
(LUMEL N27P meters) and ambient parameters: solar radiation intensity (3) - with LP PYRA 02AV pyranometer, wind speed (4) - with MAX 40H cup anemometer, ambient temperature (5) - with PT1000 meters. In addition, the temperature of cells was measured with PT1000 meters fixed directly to the surface of the panels. All the values were monitored with the use of the authors' original measurement computer system (6) with 30 s frequency and saved on the computer.

\section{Theoretical analysis}

The efficiency of solar radiation conversion into electric energy was calculated as the quotient of available energy and the amount of solar energy reaching the panels' surface, so in differential time $d \tau$ it is referred to as:

$$
\eta=\frac{\int_{0}^{\tau} E_{\text {elektr }} d \tau}{F_{P V} \cdot \int_{0}^{\tau} R_{z} d \tau}
$$

This equation, with the adopted sampling time $(\Delta \tau)$ can be expressed as:

$$
\eta=\frac{\sum E_{\text {elektr }} \cdot \Delta \tau}{\sum R_{z}^{\Delta \tau} \cdot F_{P V} \cdot 10^{-3}}
$$

where: $E_{\text {elektr }}$ - electrical power on the inverter's secondary side, $\mathrm{kW} ; R_{z^{-}}$solar radiation intensity, $\mathrm{W} / \mathrm{m}^{2} ; F_{P V^{-}}$photovoltaic panel area, $\mathrm{m}^{2} ; \Delta \tau-$ time (s).

The analysis performed involved finding a functional relation taking account of the influence of factors determining (ambient parameters) the efficiency of the panels' work. The form of the model was chosen on the basis of the highest value of determination factor and this relation was expressed with non-linear estimation with quasi-Newton method with 0.001 coefficient of convergence. The difference between values calculated and measured was determined with average square root error $(\square)$.

\section{Results and discussion}

The tests were done between February and June 2015. Detailed analysis included five days close to the socalled recommended days. Figures 2 and 3 show daily course of measured parameters for selected days: 15/02- fig. 2 and 15/06- fig. 3. 

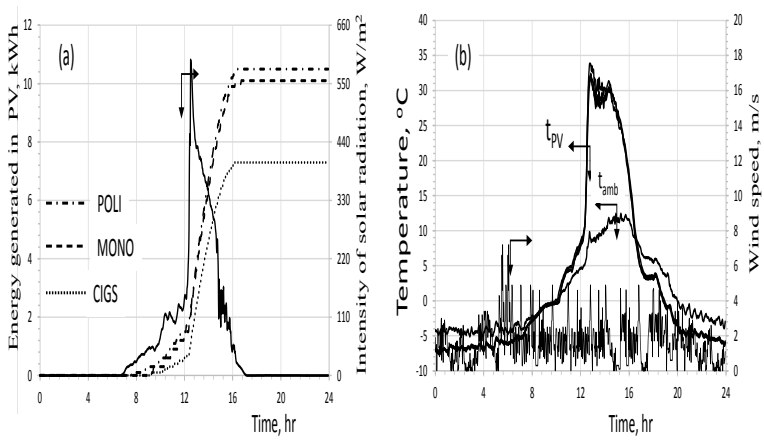

Fig. 2. Daily course of measured parameters (15/02): a) accumulated amount of energy for mono-, polycrystalline and CIGS-type panels as well as solar radiation intensity; $b$ ) and the speed of wind, cell temperature $\left(\mathrm{t}_{\mathrm{PV}}\right)$ and ambient temperature $\left(\mathrm{t}_{\mathrm{amb}}\right)$.

It is found that on the discussed day, with the total solar irradiation of nearly $1.5 \mathrm{kWh} / \mathrm{m}^{2}$ and average ambient temperature (during radiation weather) of $4.5^{\circ} \mathrm{C}$ the amount of solar energy converted into electrical energy falls within the range of 0.05 (CIGS panels) and $0.11 \mathrm{kWh} / \mathrm{m}^{2}$ (polycrystalline silicon panels). During direct solar radiation, the temperature of panels increased from approx. -5 to approx. $33^{\circ} \mathrm{C}$.
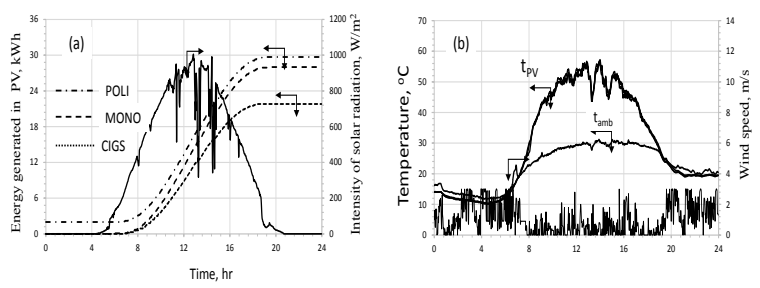

Fig. 3. Daily course of measured parameters (15/06): a) accumulated amount of energy for mono-, policrystalline and CIGS-type panels as well as solar radiation intensity; $b$ ) and the speed of wind, cell temperature $\left(\mathrm{t}_{\mathrm{PV}}\right)$ and ambient temperature $\left(\mathrm{t}_{\mathrm{amb}}\right)$.

It is found that on the discussed day, with the total solar irradiation of nearly $7.79 \mathrm{kWh} / \mathrm{m}^{2}$ and average ambient temperature (during radiation weather) of $24.8^{\circ} \mathrm{C}$ the amount of solar energy converted into electrical energy falls within the range of 0.54 (CIGS panels) and $1.02 \mathrm{kWh} / \mathrm{m}^{2}$ (polycrystalline silicon panels). During solar radiation, the temperature of panels increased from approx. 10 to approx. $57^{\circ} \mathrm{C}$.

The attempts to find a functional dependency taking account of the relation between conversion efficiency and ambient parameters failed. The diagram (fig. 4) shows the obtained changes of efficiency in the function of ambient parameters. Wind was not included in further analysis, as its influence on efficiency proved to be statistically negligent.

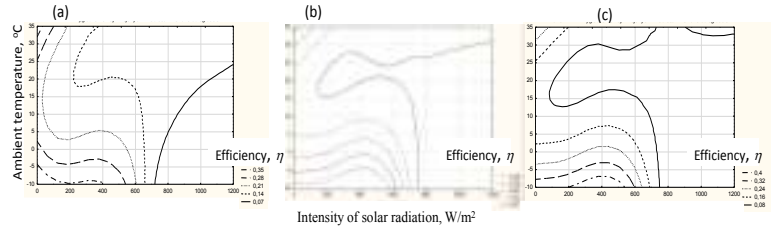

Fig. 4. The influence of ambient parameters on the modules' efficiency: (a) monocrystalline silicon, (b) polycrystalline silicon, (c) module of CIGS.

As can be seen, both the increase of solar radiation intensity and ambient temperature result in decreased efficiency of radiation conversion into electrical energy, because these parameters are partially dependent.

Calculations performed for the given months together with average ambient conditions during radiation conversion are put together in table 1 .

Table 1. Average ambient conditions with the efficiency of tested panels in individual months.

\begin{tabular}{|c|c|c|c|c|c|c|c|}
\hline \multirow[b]{3}{*}{ Month } & \multicolumn{4}{|c|}{ Ambient conditions } & \multirow{2}{*}{\multicolumn{3}{|c|}{ Panel efficiency $(\eta)$}} \\
\hline & \multicolumn{2}{|c|}{ MONO, POLY } & \multicolumn{2}{|c|}{ CIGS } & & & \\
\hline & $\begin{array}{l}\mathrm{t}_{\text {ambikint }} \\
{ }^{\circ} \mathrm{C} C\end{array}$ & $\begin{array}{c}\Sigma \mathrm{R}_{\text {extem }} \\
\text { ull } \\
\mathrm{kWh}\end{array}$ & $\stackrel{t_{\text {anbibent, }}}{{ }^{2} \mathrm{C}}$ & $\begin{array}{l}\Sigma \mathrm{R}_{\text {extena }} \\
\mathrm{l}, \mathrm{kWh}\end{array}$ & MONO & POLY & CIGS \\
\hline February & 4.19 & 1.67 & 4.21 & 1.53 & 0.123 & 0.121 & 0.093 \\
\hline March & 6.74 & 1.68 & 6.76 & 1.67 & 0.089 & 0.085 & 0.077 \\
\hline April & 11.45 & 3.31 & 11.48 & 3.27 & 0.107 & 0.106 & 0.074 \\
\hline May & 14.46 & 3.25 & 14.91 & 3.23 & 0.137 & 0.134 & 0.084 \\
\hline June & 20.93 & 5.43 & 21.03 & 4.79 & 0.096 & 0.094 & 0.054 \\
\hline
\end{tabular}

As can be seen, the average efficiency of radiation conversion during the tested period was, for: monocrystalline silicon panels 0.114 , polycrystalline silicon panels 0.108 , CIGS modules 0.076. Statistical analysis showed that only for CIGS modules (as compared to other silicon modules), the efficiency discrepancies are statistically significant. The analysis shows that both silicon panels performed conversion of solar radiation for identical ambient conditions, whereas in case of CIGS panels, conversion occurred with higher intensity of solar radiation. The performed statistical analysis did not show significant changes in ambient conditions for the periods when radiation was being converted into electrical energy.

The theory describing conversion of solar radiation into electrical energy states that as module temperature increases, the properties of its material structure change, and in consequence power on $\mathrm{p}-\mathrm{n}$ junction decreases [7]. The change of module temperature is the consequence of ambient temperature and absorption of solar radiation by the module's surface. With the use of quasi-Newton method, the authors found the model describing the temperature of panels in the function of ambient temperature and solar radiation intensity. Among the tested models, the highest value of factor $\left(\mathrm{R}^{2}\right)$ was obtained for the relation:

$t_{\text {og }}=a \cdot R_{\text {zew }}^{b}+c \cdot t_{\text {otocz }}+d$

Values of parameters $a, b, c$ and $d$ are shown in table 2.

Table 2. Values of parameters of using modules for approximating module temperature. 


\begin{tabular}{|c|c|c|c|c|c|c|}
\hline \multirow{2}{*}{ Specification } & \multicolumn{4}{|c|}{ Model parameters } & \multirow{2}{*}{$\mathrm{R}^{2}$} & \multirow{2}{*}{$\sigma^{\circ} \mathrm{C}$} \\
\hline & $a$ & $b$ & $c$ & $d$ & & \\
\hline MONO & 0.139 & 0.763 & 1.05 & -2.4 & 0.93 & 3.99 \\
\hline POLY & 0.165 & 0.729 & 1.07 & -2.38 & 0.92 & 4.18 \\
\hline CIGS & 0.105 & 0.81 & 0.977 & -1.22 & 0.9 & 4.58 \\
\hline \multicolumn{7}{|c|}{ Application scope: $2 \leq R_{\text {externa }} \leq 1080 \mathrm{~W} / \mathrm{m}^{2} ;-7.2 \leq t_{\text {ambien }} \leq 32.5^{\circ} \mathrm{C}$} \\
\hline
\end{tabular}

It can be seen that double increase in radiation intensity and ambient temperature causes module temperature (calculated in relation to initial values) to rise from 23.9 to nearly $40 \%$.

When fulfilling the paper's purpose the authors singled out the value of radiation conversion efficiency in relation to module average temperature from the available measurement data. The obtained results are shown in fig. 5 .

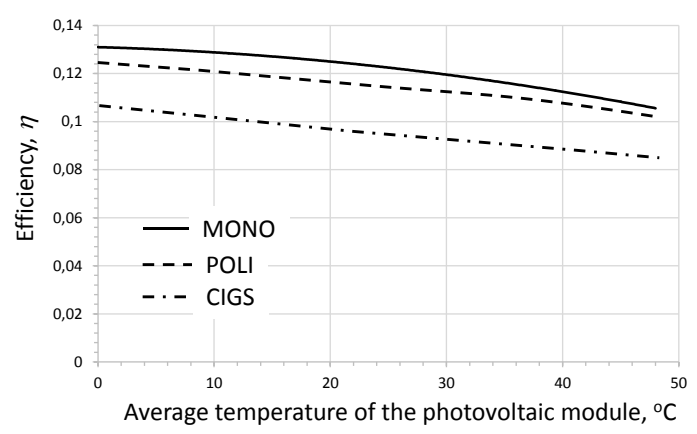

Fig. 5. Average module efficiency in the function of their temperature

It can be seen that as the module temperature increases, their efficiency falls. During the tested period, the increase of temperature from 0 to $50^{\circ} \mathrm{C}$, resulted in efficiency decreasing by 20.2 (mono modules), 20.1 (poly modules) and by $22.8 \%$ in case of CIGS modules. This phenomenon can be explained with the processes occurring in $\mathrm{p}-\mathrm{n}$ junction, where, as a result of temperature increase, there is a change in electrical charge carrier separation, the width of band gap decreases, electrokinetic potential increases and there is electrical charge dispersion. As a result, there is a decrease in solar radiation conversion into energy yield.

\section{Conclusion}

1. The average efficiency of radiation conversion in the tested ambient conditions was within the range of between 0.076 and 0.114 .

2. Double increase in radiation intensity and ambient temperature causes module temperature to rise from 23.9 to nearly $40 \%$.
3. In the tested range, temperature increase from 0 to $50^{\circ} \mathrm{C}$, causes efficiency drop by $20.1 \%$ for silicon panels and by $22.8 \%$ for CIGS panels.

Acknowledgements:

This research was financed by the Ministry of Science and Higher Education of the Republic of Poland

\section{References}

1. Hilse D., Kapała J. Inżynieria Ekologiczna, 33, 4148, (2013)

2. Latała H., Kurpaska S. Inżynieria Rolnicza 4(129), 183- 189, (2011)

3. Lu L., Yang H.X. Applied Energy 87, 3625-3631 (2010),

4. Makrides G., Zinsser B., Norton M., Georghiou G.E., Schubert M., Werner J.H. Renewable and Sustainable Energy Reviews 14, 754-762, (2010)

5. Moharil R.M., Kularni P.S. Solar Energy 84, 691702, (2010)

6. Ortega-Izquierdo M., Río del P. Renewable and Sustainable Energy Reviews 61, 372- 383, (2016)

7. Sarniak M. T., Podstawy fotowoltaiki, Oficyna Wydawnicza Polit. Warsz., (2008)

8. Schallenberg-Rodri'guez J. Renewable and Sustainable Energy Reviews 20, 219-239, (2013)

9. Schiffer H-W (2016). World Energy Resources Solar. https://www.worldenergy.org/ /.../2016/world-energy-resources-20

10. Smyrnakis A., Dimitrakis P., Normand P., Gogolides E. Microelectronic Engineering, Vol. 174, 74- 79, (2017)

11. Vahrenholt F., Luning S., Zimne Stońce. Dlaczego katastrofa klimatyczna nie nadchodzi. Alethia, Warszawa, 2014

12. Virtuani A., Strepparava D. Solar Energy 146, 113-118, (2017)

13. Zervos A. Renewable Energy Technology Roadmap $20 \% \quad$ by $2020, \quad 2009$. http://www.erec.org/fileadmin/erec_docs/Docume nts/Publications/Renewable

Energy_Technology_Roadmap.pdf

14. Zhai P., Larsen P., Millstein D., Menon S., Masanet E. The potential for avoided emissions from photovoltaic electricity in the United States. Energy 47, (2012), 443-450 